器の分解能が低い等が考えられる. 今後これらの改善に よりっより高精度な計測；左室自動抽出を可能としたい. 299. 虚血性心疾患における動脈注入 DSA の有用性

国立循環器病センター

○橋本時弘・香川雅昭

岡尚嗣・早崎正信

今回われわれは，虚血性心疾患の診断に動脈注入 DSA を行い，心筋虚血部位の推定が可能かを基礎的実験を含 め検討を行った，撮影はカテーテルを大動脈弁口に留置 し, RAO $40^{\circ}$ の体位で行う。得られたDSA 像より左室に ROI (関心領域) を設定し, 時間濃度曲線より解析を行っ た. 最終的には, 各ピクセルについて解析し, ファンク ショナルイメージとして表示することにより，心筋の相 対的血流量を推定することが可能となった。これを心筋 シンチグラフィと比較した結果76\%の一致を示したが, 横隔膜と接する部位で $60 \%$ と低值を示した。これは，横 隔膜の動きによるアーチファクトが考えられ，今後の検 討が必要である。

\section{0．DSA による脾塞栓率の測定}

高知医科大学医学部附属病院

○原坂仁詞・赤木直樹・山本 登 横田典和・下司博之・畠山高志 鈴木敦雄・沖野和弘・田和誠 森田尚亨・伊東賢二・久保嘉彦 遠山坦彦

最近, 脾機能六進症に対する治療に, 部分的脾塞栓術 (PSE) が施行されるようになっている。

今回，われわれは，DSA 装置により，術中に塞栓率を 求める方法を考案し基礎実験を行った。

脾臓を想定した流体系ファントムより得られたDSA データを，コンピュータにて T一D 曲線を描出した。

この曲線の上行脚にて，ピーク值の30\%と80\%の間で 最小二乗法により直線近似し，ファントム体積毎に傾き を求めた。この傾きの比より，塞栓率を求めた。

本法より求めた塞栓率の䛊差は $4 \%$ 以内であり，定量 的に求める方法としての有用性を認め, 臨床にも応用し, 好結果を得た。

\section{DSA の応用による門脈血流動態の解析について}

倉敷中央病院放射線科

○清川文秋・熊代正行・桐野 弡

薬師寺由美・上野寿一

倉敷中央病院情報処理室 林田芳忠

DSA を用いた経動脈的門脈造影像より,門脈本幹中央 部の時間一濃度曲線 $(\mathrm{T}-\mathrm{D}$ 曲線) を作製し，最高濃度時
間 PT, MOTT, MTTを求め, 血流動態の解析を試み た。ファントム実験により得られた結果では，流量が減 少するほど PTが遅くなり，MOTT，MTTの遅延傾向 が認められた。これは，これらの值が客観的に流量を表 わす值と考えられ，また臨床例において肝硬変症群では， 正常群に比べ PT, MOTT, MTTの有意な延長を示 し，当法による門脈血流動態の解析は有用と考えられた。 座長集約

DSA の臨床応用は形態的変化の診断と画像のディジ タル化されていることから動態的解析が行われるように なった。本セクションは脳血管, 心臓, 腹部血管を対象 とした動態的機能解析についての演題であった。

演題296,301は主として頸動脈，椎骨動脈の時間濃度 曲線から血行障害症例である内頸動脈狭窄, 脳底動脈循 環不全に, 経動脈的門脈造影から門脈の血流動態の解析 を行い臨床的に意義があった報告であり，演題 $297 ， 298$ は左心室機能の指標である $\mathrm{EF}$ (駆出率) について演題 297は撮影法の技術的因子について，演題298はマイク口 コンピュータを使用して算出する試みられた。演題 298 は 左心室に ROI を設定しダイナミックカーブを描かせ心 筋の相対的血流量を推定した。演題300は脾臓の塞栓術施 行の際DSAによりその効果をDSAの時間温度曲線か ら判定しようとする試みがなされた，以上いづれの演題 もDSAの動態的解析の新しい分野における試みがなさ れそれぞれ意義があったものと考えられる。ただし演題 それぞれに問題点も包含し, 今後の課題も残している. 機能解析を進歩させるためにも根本的には矢張り DSA の画質の向上とともに発展するものであり，この点も併 せて検討を重㸚ていく必要性を強調したい.

\section{画像理論一 5}

座長 吉田日出輝（熊本大学医療技術短期大学部）

\section{2. 散乱線を含んだ SN 比スペクトルの検討}

滋賀医大病院放射線部

○小水 満・大西英雄・本田秀人 大阪大学医療技術短期大学部

兽我部秀一

〔目的〕すでにわれわれは，第40回総会にて微小信号 を screen-film 系に撮像することで画像の SN 比スペク トルを求め信号に対する検出器の検出能を評価してきた。 通常得られる放射線画像は, 常に散乱体が存在し, これ による散乱 X 線により画像が大きく影響を受ける.そこ で今回, 散乱 X 線を加味した線状の信号による SN 比ス ペクトルから各信号に対する screen-film 系の検出能を 